\title{
Social performance and social media activity in times of pandemic: evidence from COVID-19-related Twitter activity
}

\author{
Diogenis Baboukardos \\ Corresponding author \\ University of Essex, Essex Business School, Colchester, Wivenhoe Park, CO4 3SQ \\ email: d.baboukardos@essex.ac.uk \\ Silvia Gaia \\ University of Essex, Essex Business School, Colchester, Wivenhoe Park, CO4 3SQ \\ email: sgaia@essex.ac.uk

\section{Chaoyuan She} \\ University of Essex, Essex Business School, Colchester, Wivenhoe Park, CO4 3SQ \\ email: c.she@essex.ac.uk
}

February 2021

Forthcoming in

Corporate Governance: The International Journal of Business in Society 


\title{
Social performance and social media activity in times of pandemic: evidence from COVID-19-related Twitter activity
}

\begin{abstract}
Purpose: The purpose of this study is to examine corporate disclosure of stakeholder-oriented actions on Twitter in response to COVID-19 during the pandemic outbreak and to empirically investigate if firms' social performance and their financial resilience have an impact on their engagement in, and communication of, stakeholder-oriented COVID-19 actions.

Design/methodology/approach: This study scrapes a sample of tweets communicated by major global listed firms between 1 March 2020 and 30 April 2020 and identifies disclosures that mention firm engagement in stakeholder-oriented actions in response to the COVID-19 pandemic. Cross-sectional regression analysis is employed to examine the relationship between firms' social performance and the number of tweets they post about stakeholder-oriented COVID-19 actions. Further, firms' financial resilience is examined as a moderating factor of this relationship.

Findings: The results show that firms with better social performance are more likely to engage in and hence communicate stakeholder-oriented actions for the COVID-19 pandemic on Twitter. Moreover, it is evident that firms with better social performance communicate more stakeholder-oriented actions only when they belong to industries that have not been severely impacted by the pandemic.

Originality/value: This study has two important contributions. First, this study provides contemporary evidence of corporate disclosure of firms' their stakeholder-oriented actions on Twitter in response to the COVID-19 pandemic during the initial outbreak period. Second, it reveals insights into what characteristics drive firms to engage in costly CSR activities, and promote them on social media, in a period characterized by high economic uncertainty.
\end{abstract}

Keywords: Twitter; COVID-19 pandemic; social performance; financial resilience 


\section{Social performance and social media activity in times of pandemic: evidence from COVID-19-related Twitter activity}

\section{Introduction}

The COVID-19 pandemic has been labelled as the worst economic crisis since the 1930s depression and far worse than the 2008 Global Financial Crisis (IMF, 2020). The current health crisis and subsequent lockdowns have severely and abruptly impacted global economic activities, challenging businesses operating in many industries around the world (De Vito and Gomez, 2020; Deloitte, 2020; Mattera et al., 2021). However, it has been argued that together with the challenges associated with COVID-19, the pandemic has offered firms new opportunities, particularly in relation to Corporate Social Responsibility (hereafter CSR). As the pandemic has made firms more aware of the importance of a good balance between financial, social and environmental performance for their long-term survival, firms may consider engaging more with CSR (Donthu and Gustafsson, 2020; He and Harris, 2020; Vitolla et al., 2016). Indeed, previous studies have provided evidence that firms that engage more with CSR are better protected from negative events, such as corporate scandals (Christensen, 2016; Janney and Gove, 2011; Rudkin et al., 2019), environmental scandals (Heflin and Wallace, 2017) negative press releases (Shiu and Yang, 2017) and financial crisis (Arevalo and Aravind, 2010; Lins et al., 2017; Sánchez et al., 2015). Similar findings have also been found in relation to the COVID-19 pandemic. The studies of Albuquerque et al. (2020) and Ding et al. (2020) showed that the negative market reactions to the COVID-19 pandemic during the first quarter of 2020 were less intense for firms with high environmental and social performance ${ }^{1}$, confirming that CSR is a key factor that helps firms to survive in periods of crisis.

At the same time, firms increasingly use social media to promote their CSR information (Zhou et al., 2015) and engage with their stakeholders (She and Michelon, 2019). In particular,

\footnotetext{
${ }^{1}$ In this paper we use the terms 'social performance', 'social awareness' and 'social orientation' interchangeably.
} 
during the current health crisis, Twitter has played an important role in the direct and rapid dissemination of useful information about the COVID-19 pandemic (Rosenberg et al., 2020; Rufai and Bunce, 2020). However, firms engaging with social media do not necessarily provide information of substance. As previous studies have shown, communicating CSR-related information on social media is not seen as an indication of firms doing well but merely reporting well (for instance, Lee et al., 2013). Stakeholders' opinions about a firm are only affected when firms disclose information about specific CSR-related actions they take, and not when they simply engage with social media (She and Michelon, 2019). Despite the importance of CSR and social media, as highlighted by previous studies, the extant literature has not provided any empirical evidence of how firms use social media to promote their CSR activities undertaken as a response to the COVID-19 pandemic. Research is necessary to understand what characteristics drive firms to engage in costly CSR activities, and promote them on social media, in a period characterized by high economic uncertainty.

Our study aims to contribute to this debate by investigating the following research questions. First, how firms' social performance is associated with their stakeholder-oriented actions for the COVID-19 pandemic as reported through their Twitter account, and second, what role the financial impact of the COVID-19 pandemic plays on the association between firms' social performance and Twitter-reported stakeholder-oriented actions for the COVID19 pandemic. To investigate these research questions, we focus our analysis on the early months of the COVID-19 outbreak (March-April 2020), since firms have been found to have experienced high levels of economic uncertainty during the first phase of the pandemic (Altig et al., 2020). We examine major global listed firms' Twitter activity during this period. We particularly focus on COVID-19-related tweets about the actions firms undertook to support their stakeholders, including employees, suppliers, customers and the wider community, during the pandemic. We then empirically test first, whether firms' social performance is associated 
with the number of their stakeholder-oriented actions for the COVID-19 pandemic as communicated through their Twitter account, and second, whether there is a difference in the above association between firms whose financials have been negatively impacted by the pandemic and firms whose financials have not been impacted.

Our findings show that during the pandemic outbreak firms that exhibit relatively high social performance, engage more in stakeholder-oriented actions about the pandemic and they communicate their actions through Twitter. Based on further sub-sample analysis, we also show that this positive association exists only for firms that belong to industries whose financials were not severely impacted by COVID-19, indicating that social-oriented firms operating in negatively impacted industries have focused more on their survival rather than on supporting their stakeholders.

By investigating these research questions, our study makes several important contributions to the extant literature. First, our study responds to the call of $\mathrm{He}$ and Harris (2020) for empirical studies to investigate the impact of COVID-19 on the communication strategies adopted by firms. Our study provides novel evidence of corporate disclosures of COVID-19-related actions communicated through Twitter during the initial outbreak period. We show that firms that are more socially oriented engage more in reporting COVID-19-related actions through Twitter, but only when their financials have not been severely impacted by the pandemic. Second, we contribute to the literature on CSR and social media by providing evidence that firms with high social awareness engage more with social media and respond to their stakeholders' needs with actions and not merely with words. Third, we contribute to the literature on CSR and financial resilience by showing that firms' financial resilience plays an important role in fostering the adoption of social-oriented behaviour. For firms that are facing financial difficulties, adopting social-oriented activities is more challenging than for financially resilient firms. While the former need to preserve corporate resources to guarantee the survival 
of the business, and might thus cut back on social-oriented activities, the latter might engage even more in social-oriented activities to signal their financial resilience and their strong future financial performance. Finally, our study has some important practical implications. Specifically, our findings suggest that firms that report COVID-19-related actions through Twitter are overall more socially responsible but also more financially resilient. In times of high uncertainty, stakeholders can use the information provided through such tweets to evaluate firms' social and financial performance.

The rest of this paper is structured as follows. The next section reviews the literature and develops the main hypotheses of the study. This is followed by a section that explains the research method and another section that reports the findings of the study. The final section provides some concluding remarks.

\section{Literature review and hypotheses development}

\subsection{Firms' social performance and Twitter activity}

In recent years, social media has gained a prominent role in firms' communication strategy towards their shareholders and stakeholders alike. Social media, and particularly Twitter, have been found to play an important role in reducing information asymmetry and enhancing firms' information environment. Prior to the 'social media era', firms used to disseminate information about their actions primarily through the press, which tended to focus on the few firms with high visibility (Miller, 2006). The use of social media has not only enabled firms to disseminate their news much more broadly and in a timely fashion; it also has allowed them to directly transmit information to users without them having to request it (Blankenspoor et al., 2014). These advancements have led to favourable economic consequences for firms such as higher liquidity, lower bid-ask spreads (Blankenspoor et al., 2014) and lower negative investor reactions in negative events (Lee et al., 2015). Additionally, Twitter has been found to play an 
important role in informing firms' stakeholders even when it serves as a secondary channel of information dissemination. For instance, tweets about price-sensitive announcements have been found to reduce information asymmetry (Prokofieva, 2015).

Studying social media allows us to examine whether (and how) firms respond to social issues (Gómez-Carrasco et al., 2020). According to Lee et al. (2013), firms' Twitter activity can be seen as a dialogic communication as it enables firms to communicate directly with their stakeholders. Such direct dialogic communication is regarded as being ethically superior and beneficial for both firms as it enhances their reputation and their stakeholders as it enhances their satisfaction towards the firms (Park and Reber, 2008; Rybalko and Seltzer, 2010).

Previous studies examine various phenomena related to CSR and its disclosure via social media and provide evidence that firms use social media (and particularly Twitter) to satisfy stakeholder needs, with stakeholders being responsive to this information. Lee et al. (2013) showed that firms with better CSR performance scores engage more with social media, whereas Balasubramanian et al. (2020) found that firms with Twitter accounts significantly outperform industry peers in CSR ratings. To the extent that CSR performance is a proxy of firms' endeavours to satisfy stakeholder needs, these findings support the notion that firms' CSR commitment is associated with their social media activities. The above findings have been further supported by studies that showed that stakeholders respond to firms' social media activities. For instance, Vo et al. (2019) showed that airlines with better CSR engagement received more positive word of mouth and less negative word of mouth on Twitter. Saxton et al. (2019) examined how the public reacts to CSR-focused Twitter feeds and found that public resonance was positively associated with messages that conveyed CSR topics, such as the environment or education, made the topic explicit through the use of hashtags and/or tapped into discussions of existing social movements. 
As discussed above, the extant literature suggests that firms with relatively high CSR performance engage more with social media. Especially during crises, when stakeholders need information to reduce uncertainty and negative feelings, firms' social media use plays a pivotal role in firms' endeavours to manage their stakeholders' needs (Jin et al., 2014; Murashima, 2020; Sweetser and Metzgar, 2007). It appears that 'organizations no longer have a choice about whether to integrate social media into crisis management; the only choice is how to do so' (Jin et al., 2014, p.76). Nevertheless, in times of crisis, insiders are found to communicate supplementary (and not core) CSR issues and favourable information on social media about their firm in order to legitimize their actions (Gómez-Carrasco et al., 2020). Such reporting does not require firms to do well but merely to report well, and hence it is seen as being of little credibility and usefulness by stakeholders (Mercer, 2004). Indeed, previous studies provide evidence that stakeholders' opinions about a firm are more positive when a firm communicates specific actions (and not general comments) about its CSR engagement (She and Michelon, 2019).

Based on the above discussion, a question that arises is what characteristics drive firms to engage in costly CSR activities, and promote them on social media, in a period characterized by high economic uncertainty. We posit that firms with high social awareness will respond to the COVID-19 health crisis with actions and not merely with words when it comes to their stakeholders. Although the use of a Twitter account is not a costly activity, the dissemination of information about specific actions to stakeholders in response to the COVID-19 pandemic brings important and costly implications, and hence only a few firms with high social performance should be able to engage in doing so (Bacha and Ajina, 2020). Hence, our first hypothesis is formulated as follows: 
H1. There is a positive association between firms' social performance and their Twitter activity about their stakeholder-oriented actions for the COVID-19 pandemic.

\subsection{The role of firms' financial resilience}

Furthermore, although it is argued that ' $[\mathrm{t}]$ his pandemic offers great opportunities for firms to actively engage in various CSR initiatives during the crisis...' (He and Harris, 2020, p.180), the current health crisis has led to the worst economic crisis since the 1930s depression (IMF, 2020) and severe economic consequences for firms in many industries around the world (De Vito and Gomez, 2020; Deloitte, 2020). As a consequence, there an open empirical question regarding what characteristics drive firms to engage in such costly activities in the currently uncertain economic environment.

Recent studies indicate that superior past CSR performance serves as an insurance-like mechanism, which mitigates the negative effects of the current health and consequent economic crises. Albuquerque et al. (2020) show that US firms with relatively high environmental and social performance exhibit higher stock market performance and experience less share price volatility than their counterparts with lower environmental and social performance. Similarly, Ding et al. (2020) examine a large sample of firms from 56 economies and show that the stock prices of firms with better CSR performance in the period before the pandemic were affected less negatively by the current health crisis. The focus of these studies, however, is on the effect of past CSR performance on firms' current stock market performance; no study, thus far, has examined the characteristics that drive firms to engage in costly CSR activities in such uncertain times.

Previous studies suggest that firms' CSR expenditure (and hence activities) play a signalling role in indicating financial resilience and strong future financial performance (Lys et al., 2015). It is indeed evident that investors consider firms' superior CSR performance 
costly but still positive news when they are assured that the financial implications of such performance are taken into consideration in the formal accounting system (Baboukardos, 2018). In these times of high economic uncertainty, with firms' market values collapsing around the world, it can be argued that the decision of a firm to engage in and consequently disseminate information about costly stakeholder-oriented actions for the COVID-19 pandemic is a way to signal its financial resilience and strong future financial performance. Such an argument provides an explanation for previous studies' findings, which show that the stock prices of firms with superior CSR performance are affected less negatively by the pandemic (Albuquerque et al., 2020; Ding et al., 2020).

If firms' social performance signals strong future financial performance, then the social activities undertaken during the pandemic should be evident only for firms that are considered financially resilient, whereas firms that face severe financial constraints may remain silent. Previous empirical studies, although not about CSR activities, provide evidence that firms with positive financial performance news are found to be more vocal on social media than firms with unfavourable news (Yang and Liu, 2017). Hence, drawing on the above discussion, we posit that firms' social performance is an important factor in their decision to engage with social media but that this factor is conditional to firms' financial resilience. Our second hypothesis is formulated as follows:

H2. The positive association between firms' social performance and their Twitter activity about their stakeholder-oriented actions for the COVID-19 pandemic is stronger for firms that have not been negatively impacted by the pandemic. 


\section{Research method}

\subsection{Sample and data collection}

We focus on stakeholder-oriented actions for the COVID-19 pandemic communicated by major global listed firms on Twitter between 1 March 2020 and 30 April 2020. The reason for choosing this period is because the severity of the first wave of the COVID-19 pandemic intensified between March and April 2020 in the sample countries. Figure 1 presents the performance of global major indices between 2 January 2020 and 30 June 2020. The graph shows that there was a huge decrease in cumulative returns across all major indices between 1 March and 30 April 2020, suggesting that the COVID-19 pandemic outbreak had a severe and unexpected negative impact on global firms. Therefore, global stock market performance supports our choice of sample period.

[Figure 1 about here]

We firstly identify firms that are listed in major global stock indices including S\&PUK, S\&P100, OMX Stockholm 30 Index, OMX Helsinki 25 Index, OMX Copenhagen 20 Index, Euronext100, ASX, TSX, JSE, IBEX, Swiss Market Index, CAC, BEL20, AEX and DAX. The initial number of unique firms retrieved was 660. Next, we require at least three firms in a country; this criterion reduced the size to 657 . We then excluded firms that do not have an English Twitter account and have no active use of Twitter; this process yielded a sample of 508 firms. Finally, we excluded firms with missing financial and ESG data on Thomson Reuters Eikon and those with negative equity value. The final sample consists of 483 firms.

We used Python to scrape firm-initiated tweets that were posted between 1 March 2020 and 30 April 2020; a total of 24,820 tweets were posted during this period. Following prior 
studies, we identify COVID-19-related tweets using a dictionary approach (Hassan et al., 2020; She and Michelon, 2019). We used the glossary provided by BBC and Independent articles to construct the dictionary (see Appendix A). ${ }^{2}$ A tweet was classified as being COVID-19-related if at least one of the terms from the dictionary appeared during the scanning. This process yielded 4,829 COVID-19-related tweets initially. We then manually checked each tweet to filter out those that were misclassified. This process yielded a final sample of 4,484 COVID19-related tweets.

\subsection{Empirical model}

Since our dependent variable is count data, we follow previous studies (Saxton and Waters, 2014; She and Michelon, 2019) and employ a nonlinear model based on Negative Binomial (NB) distribution where we regress the number of tweets mentioning stakeholderoriented COVID-19 actions (COVIDSTAKACT) on their social performance score (SOCIAL) and a number of control variables as follows (the $i$ subscript indicates firm) $)^{3}$ :

$$
\begin{aligned}
& \text { COVIDSTAKACT } T_{i}=\beta_{0}+\beta_{1} \text { SOCIAL }_{i}+\beta_{2} \text { SIZE }_{i}+\beta_{3} \text { ROE }_{i}+\beta_{4} L E V_{i}+\beta_{5} \text { BTM }_{i}+ \\
& \beta_{6} \text { ANAFOL }_{i}+\beta_{7} \text { EARNREL }_{i}+\beta_{8} \text { CSRCOM }_{i}+\beta_{9} \text { INDDIR }_{i}+\text { CountryFE }+ \\
& \text { IndGroupFE }+\varepsilon_{i}
\end{aligned}
$$

To test both hypotheses we focus on coefficient $\beta_{1}$ of the variable SOCIAL. For the first hypothesis (H1), we pool the total number of observations (483) and estimate the model. If our hypothesis holds, then coefficient $\beta_{1}$ should be positive and statistically significant.

\footnotetext{
2 The links to the BBC and Independent articles: https://www.bbc.co.uk/news/health-52182658 and https://www.independent.co.uk/news/health/coronavirus-key-terms-what-to-know-social-distancing-glossarya9422786.html.

${ }^{3}$ Another approach could be to employ a nonlinear model based on Poisson distribution. However, one of the assumptions for Poisson regression models is that the conditional variance should be equal to the conditional mean (Wooldridge, 2010). We initially ran the regression analysis using the Poisson model, but the goodness of fit test suggested that the dependent variable is over-dispersed; hence, we used Negative Binomial (NB) distribution. As a robustness check we also employ an OLS linear regression approach, and the results remain similar.
} 
Further, to test the second hypothesis (H2), we split our sample into firms that are more negatively impacted by COVID-19 and those that are less (or not) negatively impacted, estimate the model (1) again for both subsamples separately and compare the magnitude of the coefficient $\beta_{1}$ from both subsamples. We rely on the COVID-19 sector heatmap published by Deloitte (2020) to classify whether a firm belongs to a high or low COVID-19 impact industry. ${ }^{4}$ This heatmap outlines the impact of COVID-19 on each industry in Canada, the US, Australia, China, Japan, Germany, Italy, Spain and the UK. Each industry is assigned a value of one if there is a high impact on businesses trading and cash flows; two if there is significant disruption and a likely financial impact/loss; three if the impact is neutral or there is a low impact/loss; and four if there is a positive outlook in each country. To measure the impact of COVID-19 on our sample firms, we first compute the average outlook score of each industry across countries excluding China and Japan, since our sample firms do not include any firms from these countries. We then define an industry as having a low impact if the mean outlook score is greater and equal to 2.5 - the median of the one to four outlook score assigned by Deloitte. Finally, we map each sample firm's industry, based on the Global Industry Classification Standard (GICS), against the sector heatmap and identify firms as belonging to low or high impacted industries. The detailed industry COVID-19 impact is outlined in Appendix B.

\subsubsection{Dependent variable: tweets mentioning stakeholder-oriented COVID-19 actions}

Given that the COVID-19 pandemic has increased uncertainty among the global community, firms may choose to disseminate their responses via Twitter to widely and promptly inform their stakeholders (Blankespoor et al., 2014; Lee et al., 2015; Prokofieva, 2015). Therefore, we use the number of tweets communicating the firm's stakeholder-oriented

\footnotetext{
4 The COVID-19 sector heatmap is available at https://www2.deloitte.com/global/en/pages/aboutdeloitte/articles/Covid19/Covid19-sector-map.html.
} 
COVID-19 actions as the dependent variable (COVIDSTAKACT). We firstly manually coded each COVID-19-related tweet and identified tweets that mention firms' engagement in actions that addressed stakeholders including employees, suppliers, customers and the wider community. We did not include tweets communicating a firm's general COVID-19 response and actions specifically addressed to shareholders. We then aggregated the measure to firmlevel by computing the total number of stakeholder-oriented COVID-19 actions tweets communicated during the sample period. Examples of firms' stakeholder-oriented actions in response to the COVID-19 pandemic are illustrated in Appendix C.

\subsubsection{Firms' social performance}

We measure a firm's social performance (SOCIAL) using its ASSET4 social pillar score as of 30 April 2020. ASSET4 social pillar score evaluates a firm's performance in areas including community contribution, workforce welfare, human rights and product responsibility (Refinitive, 2020). It ranges from zero to 100, where a higher number indicates better social performance. The firms' social pillar scores were retrieved from the Thomson Reuters ASSET4 database.

\subsubsection{Control variables}

We include a number of control variables to account for other factors that may influence firms' engagement with stakeholder-oriented COVID-19 actions. We firstly control for a firm's financial performance by including firm size, return on equity, leverage and book-to-market ratio. Firm size (SIZE) is measured as the natural log of the firm's total assets. Return on equity (ROE) is computed as net income scaled by total equity. Leverage (LEV) is measured as total liabilities scaled by total equity. Boot-to-market ratio (BTM) is computed as total equity divided by the firm's market value. All financial data are measured in US dollars as of 30 April 
2020. We also control for firms' transparency practices by including the number of analysts following (ANAFOL) as prior studies argue that firms followed by more analysts tend to be more transparent (Bushman et al., 2004). We also include a dummy variable (EARNREL) that equals one if a firm's fiscal year ended in December 2019, and zero otherwise, to control for firms' earnings announcements during the sample period as firms may discuss their COVID19 actions alongside earnings news (Hassan et al., 2020). Lastly, we include two governancerelated variables: the presence of a CSR committee (CSRCOM) and the percentage of independent directors on the board (INDDIR) as prior studies find that governance plays a significant role in influencing firms' CSR activities (Dixon-Fowler et al., 2017; Mallin and Michelon, 2011). We also include country fixed effect and industry group fixed effect to control time-invariant country- and industry-level characteristics. All standard errors are robust. Variable definitions are provided in Table 1.

[Table 1 about here]

\section{Results}

\subsection{Descriptive statistics and univariate analysis}

Panel A of Table 2 presents the descriptive statistics of our sample. We find that firms on average tweeted 3.75 tweets mentioning their stakeholder-oriented actions in response to the COVID-19 pandemic. The number of tweets ranges from a minimum of zero to a maximum of 119, suggesting a large variation in firms' stakeholder-oriented actions during the sample period. Regarding firms' social performance, the average social score is 73.00 , suggesting that the sample firms have a relatively high social performance.

We further separate our sample firms into high and low COVID-19 impacted industry groups and compare their differences. Panel B of Table 2 shows that firms in low impact 
industries communicated 5.09 tweets mentioning their stakeholder-oriented actions in response to the COVID-19 pandemic, while firms in high impact industries communicated only 3.28 tweets. However, there is no significant difference in terms of social performance between the two groups. This can be seen as a preliminary confirmation of our second hypothesis as it shows that although the average social performance in the two groups is similar, the number of tweets for low impact industries is significantly larger. We also find that firms in low impact industries have a higher return on equity and a lower book-to-market ratio, suggesting that these firms enjoy better profitability and investors are more willing to invest in these firms.

[Table 2 about here]

Table 3 presents the correlation matrix of our variables, and the results suggest that there is no multicollinearity issue among the independent and control variables as the coefficients are below 0.4. An interesting finding from the univariate analysis is that the social performance variable (SOCIAL) is positively correlated to the number of tweets about stakeholder-oriented actions for the COVID-19 pandemic (COVIDSTAKACT). Finally, the VIF test (untabulated) also confirms that no multicollinearity is present as all variables have a VIF value below two.

[Table 3 about here]

\subsection{Multivariate analysis}

Table 4 presents the NB regression results of the relationship between firms' social performance and the number of tweets mentioning stakeholder-oriented actions for the COVID-19 pandemic. In Column 1, we pool all observations and find that social performance 
(SOCIAL) is positively associated with the number of tweets communicating the firm's stakeholder-oriented COVID-19 actions (COVIDSTAKACT). This finding is consistent with our first hypothesis (H1); firms with better social performance are more likely to engage in, and hence communicate, actions that help stakeholders overcome the pandemic.

[Table 4 about here]

To test the second hypothesis, we split our sample into high and low impact industry groups and estimate the model again. Our findings indicate that firms' social performance is positively and strongly associated with the number of tweets mentioning stakeholder-oriented actions for the COVID-19 pandemic only in the low impact industries subgroup. On the contrary, no significant relationship is found between social performance and the number of stakeholder-oriented COVID-19 actions tweets in high impact industries. The results are consistent with our second hypothesis $(\mathrm{H} 2)$, which posits that firms engage in and communicate their stakeholder-oriented actions about the COVID-19 pandemic only when they belong to low impact industries; hence, they use Twitter to signal strong future financial performance and resilience. In contrast, when firms are severely impacted by COVID-19, they may preserve their resources and focus more on business survival.

\subsection{Robustness checks}

To ensure the robustness of our results, we conduct several additional tests. We firstly re-run our regression model by adding the low impact industry indicator (LOWIMPACT) and an interaction term between firms' social performance and the low impact industry indicator (SOCIAL $\times$ LOWIMPACT) into the model. Table 5 presents the results and shows that, similar to our main analysis, the interaction term between social performance and low impact industry 
indicator exhibits a positive and significant effect, suggesting that when firms are impacted less by COVID-19, they engage more in actions that help stakeholders to overcome the pandemic.

[Table 5 about here]

Next, we use the overall CSR performance of a firm as an alternative measure of its social performance. Consistent with our main findings, the results in Table 6 show that the number of tweets mentioning stakeholder-oriented COVID-19 actions is positively related to CSR performance, suggesting that firms with better CSR performance are more likely to engage in and disseminate news about their actions to stakeholders. Also, the results hold only for firms belonging to low impact industries, thus confirming our second hypothesis.

[Table 6 about here]

In addition, we also replace the dependent variable with the number of tweets mentioning firms' general actions taken in response to COVID-19 including actions addressed to stakeholders, shareholders and the business community in general. The results in Table 7 show that firms with high social performance continue to show a positive relationship with the number of tweets mentioning the firms' general COVID-19 response, suggesting that firms with higher social performance engaged in more COVID-19 actions during the sample period. The results for testing the second hypothesis remain unchanged.

[Table 7 about here] 
Furthermore, we take the natural logarithm of the number of tweets mentioning stakeholder-oriented actions for the COVID-19 pandemic and re-run the main regression analyses using an OLS linear model. The results in Table 8 confirm our main regression findings, where social performance depicts a positive association with tweets mentioning stakeholder-oriented COVID-19 actions, but only for firms that belong to low impact industries.

[Table 8 about here]

Finally, we perform the test for a subsample of firms that reside in countries that have been impacted the most by the pandemic in terms of the COVID-19 death rate. We retrieve the total number of confirmed deaths as of 30 April 2020 from the Coronavirus Government Response Tracker database (Hale et al., 2020) and compute the death rate per one million population. ${ }^{5}$ Next, we identify countries that have a death rate above the median value and rerun the regression tests. The results, shown in Table 9, are consistent with our main findings, where social performance depicts a positive association with tweets mentioning stakeholderoriented COVID-19 actions only for firms that are less impacted by the pandemic. Therefore, our findings still hold when using a subsample of firms that reside in countries with a high COVID-19 death rate.

[Table 9 about here]

\footnotetext{
${ }^{5}$ Countries' population data was retrieved from worldometer.com.
} 
Overall, the robustness tests support our hypotheses; namely, that firms with better social performance that are less impacted by COVID-19 are more likely to engage in COVID19 actions for stakeholders.

\section{Concluding remarks}

Considering the important role that social media plays in firms' communication with their stakeholders and recent calls for studies on the communication strategies adopted by firms during the COVID-19 pandemic (He and Harris, 2020), our study examines firms' Twitter activity in light of the recent health and economic crises due to the COVID-19 pandemic.

Specifically, we draw from a sample of large firms worldwide and empirically show that firms with superior social performance tweet significantly more about their COVID-19related actions to their stakeholders. Our findings contribute to the extant literature, which argues that stakeholders react positively to firms' social media activity only when their activity is connected to specific actions and does not merely provide generic information (She and Michelon, 2019). Considering that firms with superior social performance aim to address their stakeholders' needs more adequately (Baboukardos et al., 2021), our study provides evidence of what characteristics drive firms to engage in costly CSR activities, and promote them on social media, in a period characterized by high economic uncertainty.

Further, we provide evidence that the effect of firms' social awareness (as proxied by their social performance score by Thomson Reuters ASSET4) on their COVID-19-related Twitter activity is conditional to their financial resilience. Specifically, we find that the association between firms' social performance and their tweets about stakeholder-oriented COVID-19 actions holds only for firms that have not been negatively impacted by the pandemic. Our findings are in line with previous studies, which show that firms engage in costly CSR activities in order to signal their financial resilience and strong future financial 
performance (Lys et al., 2015; Samy et al., 2010). These results provide an explanation for recent findings that indicate an association between firms' superior CSR performance and superior (i.e. less negative) stock market performance during the COVID-19 pandemic (Albuquerque et al., 2020; Ding et al., 2020).

Despite its contributions, our study also has limitations which, in turn, open avenues for future research. First, our study considers only the tweets on COVID-19 actions released during the first wave of the pandemic. However, a more comprehensive picture could be formed if a longer window is considered. Future studies can extend our analysis by considering tweets released during the second wave, which is taking place at the time this paper is being written. Second, as this paper is written while the pandemic is still unfolding, we do not examine the potential long-term effects of the crisis on firms. The long-term implications of the pandemic are an important issue, and we urge future research to address this topic. Third, we only consider the disclosure of stakeholder-oriented actions on Twitter, while firms may use alternative channels of communication. Future studies can complement our study by analysing these alternative communication channels. Finally, our study draws on previous studies and argues that firms' social-oriented Twitter activity signals strong future financial performance. We urge future studies to examine whether indeed firms with superior Twitter activity about CSR issues during the pandemic exhibit superior financial performance after the pandemic. 


\section{Appendices}

\section{Appendix A. Examples of Stakeholder-Oriented COVID-19 Actions Communicated on}

\section{Twitter}

To help fight \#COVID-19 our employees are using industrial-scale \#3Dprinters to rapidly produce face shields for the \#NHS. Combined with designs manufactured by our supply chain, we aim to deliver more than 145,000 to the frontline. \#InThisTogether http://baes.co/TzAK50zfODM (@BAESystemsplc, 16 April 2020)

To help support those in communities most affected by the coronavirus situation, we're donating $£ 1$ million to The Big Night In Appeal and will be matching all customer donations through our link up to £1 million. For full T\&Cs see https://barc.ly/2KmDHSV (@BarclaysUK, 22 April 2020)

Our newly established testing laboratory in Berlin which supports the fight against the \#Coronavirus is already running: In the lab, our employees " more than 140 have volunteered " are able to conduct up to 1,000 additional SARS-CoV-2 tests per day. https://www.bayer.com/en/coronavirus-covid-19-update.aspx (@Bayer, 1 April 2020)

Our Operations team at the Angostura facility in Trinidad and Tobago are diligently working together to ensure that our people and operations remain safe during the COVID-19 pandemic. This includes regular temperature screenings at site.pic.twitter.com/11ozqhSmhr (@bhp, 23 March 2020)

We are delighted to become a major partner of The National Emergencies Trust. @ NatEmergTrust's Coronavirus Appeal will ensure help gets quickly and efficiently to those who are most in need, particularly older and more vulnerable people. \#coronavirushttps://www.linkedin.com/pulse/trusted-times-need-kerensa jennings/?trackingId=6Wnp1Xlf1IZdNBtRiUqIgg\%3D\%3D (@BTGroup, 2 April 2020)

KO: Beginning in mid-March, consumer traffic began to decline significantly due to the impact of COVID-19, as we temporarily closed some restaurants and shifted to limited operations in others. \$MCD (@McDonaldsCorp, 30 April 2020) 
Appendix B. Deloitte COVID-19 Sector Heatmap

\begin{tabular}{|c|c|c|c|c|c|c|c|c|c|}
\hline Industries & Canada & US & Australia & Germany & Italy & Spain & UK & Mean & Lowimpact \\
\hline Automotive & 1 & 1 & 1 & 1 & 1 & 1 & 2 & 1.14 & 0 \\
\hline Aerospace \& Defence & 1 & 2 & 4 & 1 & 2 & 2 & 1 & 1.86 & 0 \\
\hline Shipping \& Ports & 2 & 2 & - & 2 & 1 & 2 & 1 & 1.67 & 0 \\
\hline Airlines & 1 & 1 & - & 1 & 1 & 1 & 1 & 1.00 & 0 \\
\hline Banking & 2 & 2 & 3 & 2 & 2 & 3 & 3 & 2.43 & 0 \\
\hline Food \& Beverage & 4 & 3 & 3 & 4 & 2 & 4 & 3 & 3.29 & 1 \\
\hline MedTech & 1 & 2 & 2 & 4 & 4 & 2 & 2 & 2.43 & 0 \\
\hline Apparel \& Footwear & 1 & 1 & 2 & 2 & 1 & 1 & 2 & 1.43 & 0 \\
\hline Personal \& Household Goods & 4 & 3 & 3 & 4 & 3 & 2 & 2 & 3.00 & 1 \\
\hline Drug \& Pharmacy & 4 & 4 & 3 & 4 & 4 & 4 & 4 & 3.86 & 1 \\
\hline Grocery \& Convenience Stores & 4 & 4 & 4 & 4 & 2 & 4 & 4 & 3.71 & 1 \\
\hline Mass \& Discount Stores & 4 & 4 & 1 & 4 & 1 & 2 & 1 & 2.43 & 0 \\
\hline $\begin{array}{l}\text { Specialty Stores \& Luxury } \\
\text { Goods (Non-essentials) }\end{array}$ & 2 & 1 & 1 & 2 & 1 & 1 & 1 & 1.29 & 0 \\
\hline Wholesale \& Distribution & 2 & 2 & 2 & 2 & 2 & 2 & 1 & 1.86 & 0 \\
\hline Cruise Lines & 1 & 2 & - & 1 & 1 & 1 & 1 & 1.17 & 0 \\
\hline $\begin{array}{l}\text { Hotels, Restaurants, Health \& } \\
\text { Wellness }\end{array}$ & 1 & 1 & - & 2 & 1 & 1 & 1 & 1.17 & 0 \\
\hline Engineering \& Construction & 2 & 3 & - & 2 & 2 & 2 & 2 & 2.17 & 0 \\
\hline Industrial Products & 2 & 2 & - & 2 & 2 & 2 & 3 & 2.17 & 0 \\
\hline Mining \& Metals & 2 & 3 & 2 & - & 2 & 2 & 3 & 2.33 & 0 \\
\hline Construction \& Base Materials & 1 & - & 2 & - & 2 & 1 & 1 & 1.40 & 0 \\
\hline $\begin{array}{l}\text { Chemicals \& Specialty } \\
\text { Materials }\end{array}$ & 2 & 1 & 2 & 2 & 2 & 3 & 1 & 1.86 & 0 \\
\hline Oil \& Gas & 1 & 1 & 2 & 1 & 2 & 2 & 1 & 1.43 & 0 \\
\hline Power \& Utilities & 3 & 3 & 3 & 3 & 3 & 3 & 3 & 3.00 & 1 \\
\hline Renewable Energy & 2 & 3 & 3 & 4 & 3 & 3 & 3 & 3.00 & 1 \\
\hline Capital Markets & 1 & 2 & - & 2 & 2 & 2 & 3 & 2.00 & 0 \\
\hline Payments & - & 2 & - & 3 & - & 2 & - & 2.33 & 0 \\
\hline Property \& Casualty & 2 & 2 & 2 & 2 & 2 & 3 & 2 & 2.14 & 0 \\
\hline Life, Health \& Savings & 2 & 2 & - & 2 & 2 & 2 & 2 & 2.00 & 0 \\
\hline Asset Management & 1 & 2 & 1 & 4 & 2 & 1 & 3 & 2.00 & 0 \\
\hline Developers \& Homebuilders & 1 & 2 & - & 3 & 2 & 1 & 1 & 1.67 & 0 \\
\hline Real Estate Services \& Brokers & 1 & 2 & 2 & 3 & 1 & 1 & 1 & 1.57 & 0 \\
\hline $\begin{array}{l}\text { Health Care Providers, Health } \\
\text { Plans \& Payers }\end{array}$ & 1 & 2 & 3 & 4 & 2 & 2 & 2 & 2.29 & 0 \\
\hline Bio Pharma \& Generics & 2 & 3 & 4 & 4 & 4 & 2 & 2 & 3.00 & 1 \\
\hline Technology & 2 & 2 & 2 & 2 & 3 & 3 & 4 & 2.57 & 1 \\
\hline $\begin{array}{l}\text { Digital Entertainment, Info } \\
\text { Services \& Publishing }\end{array}$ & 2 & 2 & 2 & 2 & 2 & 2 & 3 & 2.14 & 0 \\
\hline Sports \& Live Entertainment & 1 & 1 & 1 & 1 & 2 & 2 & 3 & 1.57 & 0 \\
\hline Telecom & 3 & 2 & 4 & 3 & 3 & 3 & 3 & 3.00 & 1 \\
\hline $\begin{array}{l}\text { REITs / Owners - Operators / } \\
\text { Private Equity Real Estate }\end{array}$ & 1 & 2 & 1 & 2 & 2 & 2 & 1 & 1.57 & 0 \\
\hline
\end{tabular}




\section{Appendix C. COVID-19-Related Terms}

"Covid", "Coronavirus*", "SARS", "social distanc*", "self isolation", "PPE", "personal protective equipment*", "mask*", "visor*", "face shield*", "glove*", "apron*", "pandemic", "MERS", "lockdown", "virus*", "cdc", "asymptomatic", "epidemic", "quarantine", "respirator*", "ventilator*", "contagious", "infectious", "droplet*", "community spread", "epidemiology", "furlough*", "immunity", "physical distanc*", "RO", "face covering*", "N95", "BiPap machine", "layoff*", "job cut*", "nhs", "doctor*", "nurse*", "medical staff", "frontline", "job retention", "health care worker*", "healthcare worker*", "health care staff", "healthcare staff*", "health and safety 


\section{References}

Albuquerque, R., Koskinen, Y., Yang, S., \& Zhang, C. (2020). Resiliency of environmental and social stocks: An analysis of the exogenous COVID-19 market crash. The Review of Corporate Finance Studies ahead-of-print https://doi.org/10.1093/rcfs/cfaa011

Altig, D., Baker, S., Barrero, J. M., Bloom, N., Bunn, P., Chen, S., Davis S. J., Brent Meyer, J. L., Mihaylov, E., Mizen P., Parker, N., Renault, T., Smietanka, P., \& Thwaites, G. (2020). Economic uncertainty before and during the COVID-19 pandemic, Journal of Public Economics, 191, 104274. ahead-of-print https://doi.org/10.1016/j.jpubeco.2020.104274.

Arevalo, J.A. and Aravind, D. (2010). The impact of the crisis on corporate responsibility: the case of UN global compact participants in the USA, Corporate Governance, 10(4), 406420.

Baboukardos, D. (2018). The valuation relevance of environmental performance revisited: The moderating role of environmental provisions. The British Accounting Review, 50(1), 3247.

Baboukardos, D., Mangena, M., \& Ishola, A. (2021). Integrated thinking and sustainability reporting assurance: International evidence. Business Strategy and the Environment. ahead-of-print https://doi.org/10.1002/bse.2695

Balasubramanian, S. K., Fang, Y., \& Yang, Z. (2020). Twitter Presence and Experience Improve Corporate Social Responsibility Outcomes. Journal of Business Ethics, ahead-ofprint https://doi.org/10.1007/s10551-020-04537-X

Bacha, S. and Ajina, A. (2019). CSR performance and annual report readability: evidence from France, Corporate Governance, 20(2), 201-215.

Blankespoor, E., Miller, G. S., \& White, H. D. (2014). The Role of Dissemination in Market Liquidity: Evidence from Firms' Use of Twitter ${ }^{\mathrm{TM}}$. The Accounting Review, 89(1), 79-112.

Bushman, R. M., Piotroski, J. D., \& Smith, A. J. (2004). What determines corporate transparency? Journal of Accounting Research, 42(2), 207-252.

Christensen, D. M. 2016. Corporate accountability reporting and high-profile misconduct. The Accounting Review, 91(2), 377-399.

De Vito, A., \& Gomez, J. P. (2020). Estimating the COVID-19 cash crunch: Global evidence and policy. Journal of Accounting and Public Policy, 39(2). 106741.

Deloitte (2020) COVID-19 sector heatmaps. https://www2.deloitte.com/global/en/pages/about-deloitte/articles/covid-19/covid-19sector-map.html

Ding, W., Levine, R., Lin, C., \& Xie, W. (2020). Corporate immunity to the COVID-19 pandemic (No. w27055). National Bureau of Economic Research. https://www.nber.org/papers/w27055

Dixon-Fowler, H. R., Ellstrand, A. E., \& Johnson, J. L. (2017). The Role of Board Environmental Committees in Corporate Environmental Performance. Journal of Business Ethics, 140(3), 423-438.

Donthu, N., \& Gustafsson, A. (2020). Effects of COVID-19 on business and research. Journal of Business Research, 117, 284-289.

Fernández Sánchez, J.L., Luna Sotorrío, L. and Baraibar Diez, E. (2015). The relationship between corporate social responsibility and corporate reputation in a turbulent environment: Spanish evidence of the Ibex35 firms, Corporate Governance, 15(4), 563575.

Gómez-Carrasco, P., Guillamón-Saorín, E., \& García Osma, B. (2020). Stakeholders versus Firm Communication in Social Media: The Case of Twitter and Corporate Social Responsibility Information. European Accounting Review, ahead-of-print https://doi.org/10.1080/09638180.2019.1708428 
Hale, T., Petherick, A., Phillips, T., \& Webster, S. (2020). Variation in government responses to COVID-19. Blavatnik School of Government working paper 32. Retrieved from https://www.bsg.ox.ac.uk/sites/default/files/2020-12/BSG-WP-2020-032-v10.pdf

Accessed: 5 January 2021.

Hassan, T. A., Hollander, S., van Lent, L., \& Tahoun, A. (2020). Firm-level exposure to epidemic diseases: Covid-19, SARS, and H1N1. National Bureau of Economic Research working paper 26971. Retrieved from https://www.nber.org/papers/w26971 Accessed: 1 December 2020.

He, H., \& Harris, L. (2020). The Impact of Covid-19 Pandemic on Corporate Social Responsibility and Marketing Philosophy. Journal of Business Research, 116, 176-182.

Heflin, F., and D. Wallace. 2017. The BP oil spill: Shareholder wealth effects and environmental disclosures. Journal of Business Finance \& Accounting, 44(3-4), 337-374.

International Monetary Fund (2020). The Great Lockdown: Worst Economic Downturn Since the Great Depression. Retrieved from: https://blogs.imf.org/2020/04/14/the-greatlockdown-worst-economic-downturn-since-the-great-depression/. $\quad$ Accessed: 20 September 2020.

Janney, J. J., and S. Gove. 2011. Reputation and corporate social responsibility aberrations, trends, and hypocrisy: Reactions to firm choices in the stock option backdating scandal. Journal of Management Studies, 48(7), 1562-1585.

Jin, Y., Liu, B. F., \& Austin, L. L. (2014). Examining the role of social media in effective crisis management: The effects of crisis origin, information form, and source on publics' crisis responses. Communication Research, 41(1), 74-94.

Lee, L. F., Hutton, A. P., \& Shu, S. (2015). The Role of Social Media in the Capital Market: Evidence from Consumer Product Recalls. Journal of Accounting Research, 53(2), 367404.

Lee, K., Oh, W. Y., \& Kim, N. (2013). Social media for socially responsible firms: Analysis of Fortune 500's Twitter profiles and their CSR/CSIR ratings. Journal of Business Ethics, 118(4), 791-806.

Lins, K. V., H. Servaes, and A. Tamayo. 2017. Social capital, trust, and firm performance: The value of corporate social responsibility during the financial crisis. Journal of Finance, 72(4), 1785-1824.

Lys, T., Naughton, J. P., \& Wang, C. (2015). Signaling through corporate accountability reporting. Journal of Accounting and Economics, 60(1), 56-72.

Mallin, C., \& Michelon, G. (2011). Board reputation attributes and corporate social performance: An empirical investigation of the US Best Corporate Citizens. Accounting and Business Research, 41(2), 119-144.

Mattera, M., Soto Gonzalez, F., Alba Ruiz-Morales, C. and Gava, L. (2021). Facing a global crisis - how sustainable business models helped firms overcome COVID, Corporate Governance, ahead-of-print https://doi.org/10.1108/CG-07-2020-0309

Murashima, M. (2020). Do investors' reactions to CSR-related news communication differ by shareholder? An empirical analysis from Japan, Corporate Governance, 20(5), 781-796.

Mercer, M. (2004). How do investors assess the credibility of management disclosures?. Accounting Horizons, 18(3), 185-196.

Miller, G. 2006. The press as a watchdog for accounting fraud. Journal of Accounting Research, 44(5), 1001-1033.

Park, H., \& Reber, B. H. (2008). Relationship building and the use of Web sites: How Fortune 500 corporations use their Web sites to build relationships. Public Relations Review, 34(4), 409-411. 
Prokofieva, M. (2015). Twitter-Based Dissemination of Corporate Disclosure and the Intervening Effects of Firms' Visibility: Evidence from Australian-Listed Companies. Journal of Information Systems, 29(2), 107-136.

Refinitive. (2020). Environmental, Social and Governance (ESG) Scores From Refinitiv. Retrieved from https://www.refinitiv.com/content/dam/marketing/en_us/documents/methodology/esgscores-methodology.pdf Accessed: 25 June 2020.

Rosenberg, H., Syed, S., \& Rezaie, S. (2020). The Twitter pandemic: The critical role of Twitter in the dissemination of medical information and misinformation during the COVID-19 pandemic. Canadian Journal of Emergency Medicine, 22(4), 418-421.

Rudkin, B., Kimani, D., Ullah, S., Ahmed, R., \& Farooq, S. U. (2019). Hide-and-seek in corporate disclosure: evidence from negative corporate incidents. Corporate Governance, 19(1), 158-175.

Rufai, S. R., \& Bunce, C. (2020). World leaders' usage of Twitter in response to the COVID19 pandemic: a content analysis. Journal of Public Health, 42(3), 510-516.

Rybalko, S., \& Seltzer, T. (2010). Dialogic communication in 140 characters or less: How Fortune 500 companies engage stakeholders using Twitter. Public Relations Review, 36(4), 336-341.

Samy, M., Odemilin, G., \& Bampton, R. (2010). Corporate social responsibility: a strategy for sustainable business success. An analysis of 20 selected British companies. Corporate Governance, 10(2), 203-217.

Saxton, G. D., Gómez, L., Ngoh, Z., Lin, Y. P., \& Dietrich, S. (2019). Do CSR messages resonate? Examining public reactions to firms' CSR efforts on social media. Journal of Business Ethics, 155(2), 359-377.

Saxton, G. D., \& Waters, R. D. (2014). What do Stakeholders Like on Facebook? Examining Public Reactions to Nonprofit Organizations' Informational, Promotional, and Community-Building Messages. Journal of Public Relations Research, 26(3), 280-299.

She, C., \& Michelon, G. (2019). Managing stakeholder perceptions: Organized hypocrisy in CSR disclosures on Facebook. Critical Perspectives on Accounting, 61, 54-76.

Shiu, Y.-M., and S.-L. Yang. 2017. Does engagement in corporate social responsibility provide strategic insurance-like effects? Strategic Management Journal, 38(2), 455-470.

Vitolla, F., Rubino, M. and Garzoni, A. (2017). The integration of CSR into strategic management: a dynamic approach based on social management philosophy, Corporate Governance, 17(1), 89-116.

Wooldridge, J. M. (2010). Econometric analysis of cross section and panel data. MIT press.

Yang, J. H., \& Liu, S. (2017). Accounting narratives and impression management on social media. Accounting and Business Research, 47(6), 673-694.

Zhou, M., Lei, L., Wang, J., Fan, W., \& Wang, A. G. (2015). Social media adoption and corporate disclosure. Journal of Information Systems, 29(2), 23-50. 


\section{Figure}

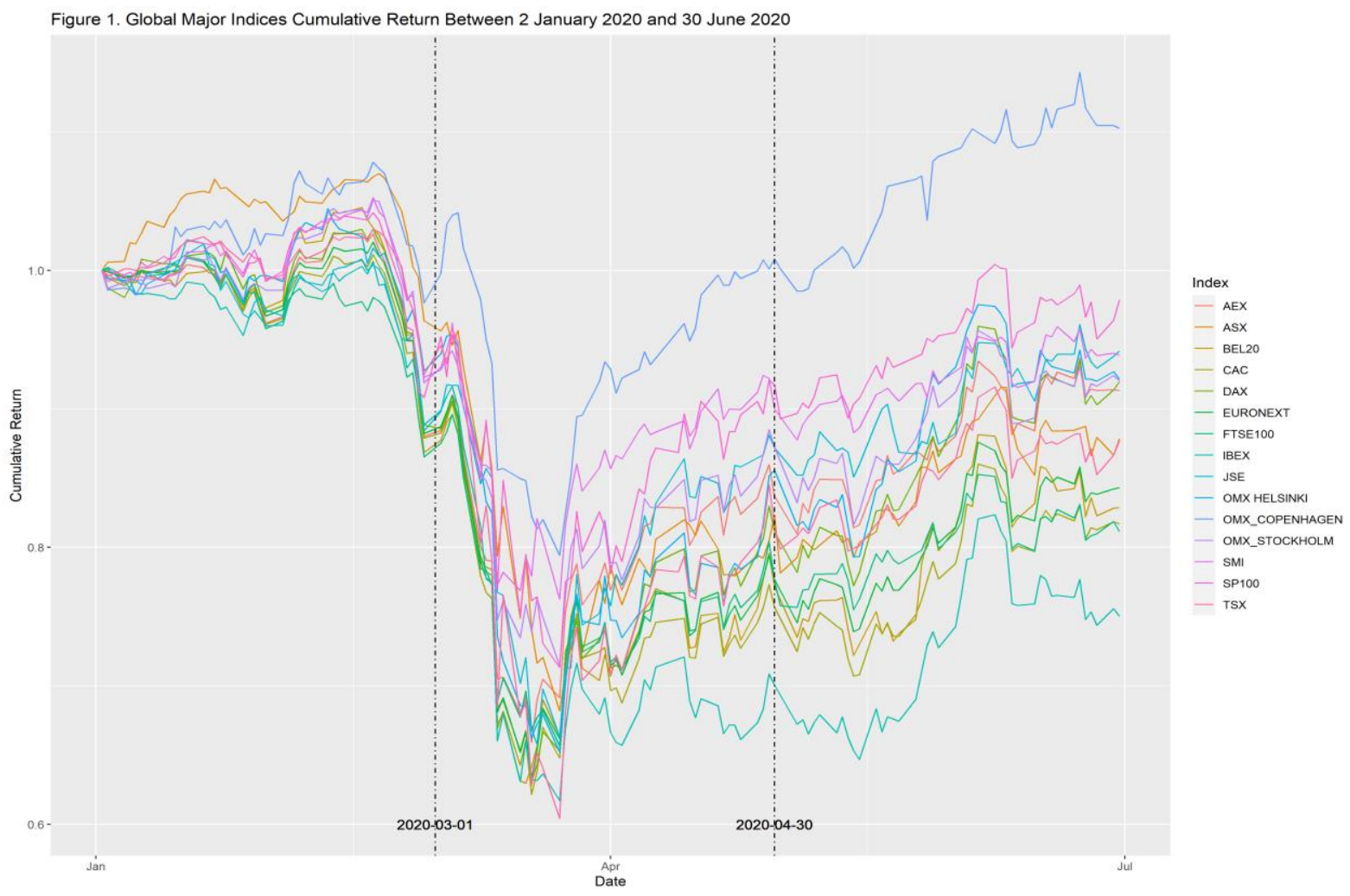




\section{Tables}

\section{Table 1. Variable definitions and data sources}

\begin{tabular}{|c|c|c|}
\hline Variables & Definition & Data Source \\
\hline COVIDSTAKACT & $\begin{array}{l}\text { The number of firm-initiated tweets mentioning firm } \\
\text { COVID-19 actions addressing to stakeholders. }\end{array}$ & Twitter \\
\hline SOCIAL & $\begin{array}{l}\text { Firm's social performance, measured using ASSET4 social } \\
\text { pillar score as of } 30^{\text {th }} \text { April } 2020\end{array}$ & Thomson Reuters Eikon \\
\hline SIZE & $\begin{array}{l}\text { Firm size, measured as the natural log of firm's total assets } \\
\text { measured in USD as of } 30^{\text {th }} \text { April } 2020 \text {. }\end{array}$ & Thomson Reuters Eikon \\
\hline$R O E$ & $\begin{array}{l}\text { Return on equity, measured as net income divided by total } \\
\text { equity in USD as of } 30^{\text {th }} \text { April } 2020 .\end{array}$ & Thomson Reuters Eikon \\
\hline$L E V$ & $\begin{array}{l}\text { Leverage, measured as total liabilities divided by total equity } \\
\text { in USD as of } 30^{\text {th }} \text { April } 2020 .\end{array}$ & Thomson Reuters Eikon \\
\hline$B T M$ & $\begin{array}{l}\text { Book-to-market ratio, measured as total equity divided by } \\
\text { firm market value in USD as of } 30^{\text {th }} \text { April } 2020 \text {. }\end{array}$ & Thomson Reuters Eikon \\
\hline ANAFOL & $\begin{array}{l}\text { Analyst coverage, measured as the number of analysts } \\
\text { following the firm as of } 30^{\text {th }} \text { April } 2020 .\end{array}$ & Thomson Reuters Eikon \\
\hline EARNREL & $\begin{array}{l}\text { A dummy variable equals one if the firm has a fiscal year } \\
\text { ended in December } 2019 \text { and zero otherwise. }\end{array}$ & Thomson Reuters Eikon \\
\hline CSRCOM & $\begin{array}{l}\text { A dummy variable equals one if the firm has a CSR } \\
\text { committee and zero otherwise. }\end{array}$ & Thomson Reuters Eikon \\
\hline INDDIR & The percentage of independent directors. & Thomson Reuters Eikon \\
\hline
\end{tabular}


Table 2. Descriptive statistics

\begin{tabular}{|c|c|c|c|c|c|c|c|c|c|}
\hline \multicolumn{10}{|c|}{ Panel A. Descriptive statistics for the whole sample } \\
\hline Variables & No. & Mean & SD & Min & $\mathbf{P 2 5}$ & \multicolumn{2}{|c|}{ P50 } & P75 & Max \\
\hline COVIDSTAKACT & 483 & 3.75 & 7.21 & 0.00 & 0.00 & \multicolumn{2}{|c|}{2.00} & 5.00 & 119.00 \\
\hline SOCIAL & 483 & 73.00 & 17.16 & 0.75 & 63.27 & \multicolumn{2}{|c|}{75.89} & 86.03 & 97.83 \\
\hline SIZE & 483 & 24.12 & 1.75 & 19.44 & 22.92 & \multicolumn{2}{|c|}{24.00} & 25.31 & 28.63 \\
\hline$R O E$ & 483 & 0.20 & 1.01 & -1.37 & 0.07 & \multicolumn{2}{|c|}{0.12} & 0.20 & 21.60 \\
\hline$L E V$ & 483 & 4.79 & 14.04 & 0.10 & 1.03 & \multicolumn{2}{|c|}{1.75} & 3.73 & 231.39 \\
\hline BTM & 483 & 0.91 & 1.64 & 0.00 & 0.26 & \multicolumn{2}{|c|}{0.55} & 1.13 & 30.80 \\
\hline$A N A F O L$ & 483 & 19.17 & 7.54 & 2.00 & 14.00 & \multicolumn{2}{|c|}{19.00} & 24.00 & 52.00 \\
\hline EARNREL & 483 & 0.70 & 0.46 & 0.00 & 0.00 & \multicolumn{2}{|c|}{1.00} & 1.00 & 1.00 \\
\hline CSRCOM & 483 & 0.86 & 0.35 & 0.00 & 1.00 & \multicolumn{2}{|c|}{1.00} & 1.00 & 1.00 \\
\hline INDDIR & 483 & 73.01 & 19.77 & 0.00 & 60.00 & \multicolumn{2}{|c|}{77.78} & 88.89 & 100.00 \\
\hline \multicolumn{10}{|c|}{ Panel B. Differences between low and high impact industries } \\
\hline & \multicolumn{3}{|c|}{$\begin{array}{l}\text { Low Impact Industries } \\
\qquad(\mathbf{N}=126)\end{array}$} & \multicolumn{4}{|c|}{$\begin{array}{l}\text { High Impact Industries } \\
\qquad(\mathbf{N}=357)\end{array}$} & \multicolumn{2}{|r|}{$\begin{array}{c}\text { t-test } \\
\text { Differences } \\
\text { (two tail) }\end{array}$} \\
\hline Variables & Mean & Median & SD & Mean & \multicolumn{2}{|c|}{ Median } & \multicolumn{2}{|l|}{ SD } & \\
\hline COVIDSTAKACT & 5.09 & 3.00 & 11.32 & 3.28 & \multicolumn{2}{|c|}{2.00} & \multicolumn{2}{|l|}{4.95} & $1.80 * *$ \\
\hline SOCIAL & 75.00 & 76.99 & 16.53 & 72.30 & \multicolumn{2}{|c|}{75.04} & \multicolumn{2}{|l|}{17.35} & 2.70 \\
\hline SIZE & 24.04 & 24.13 & 1.39 & 24.14 & \multicolumn{2}{|c|}{23.76} & \multicolumn{2}{|l|}{1.86} & 0.10 \\
\hline$R O E$ & 0.33 & 0.12 & 1.93 & 0.15 & \multicolumn{2}{|c|}{0.11} & \multicolumn{2}{|l|}{1.86} & $0.17 *$ \\
\hline$L E V$ & 3.34 & 1.79 & 11.35 & 5.30 & \multicolumn{2}{|c|}{1.75} & \multicolumn{2}{|l|}{0.25} & 1.96 \\
\hline BTM & 0.51 & 0.40 & 0.43 & 1.04 & \multicolumn{2}{|c|}{0.67} & \multicolumn{2}{|l|}{14.85} & $0.53 * * *$ \\
\hline$A N A F O L$ & 19.67 & 19.00 & 7.19 & 19.00 & \multicolumn{2}{|c|}{19.00} & \multicolumn{2}{|l|}{1.87} & 0.67 \\
\hline EARNREL & 0.70 & 1.00 & 0.46 & 0.70 & & & 7.66 & & 0 \\
\hline CSRCOM & 0.86 & 1.00 & 0.35 & 0.86 & & & 0.46 & & 0 \\
\hline INDDIR & 69.10 & 69.62 & 20.50 & 74.39 & & & 0.35 & & $5.30 * * *$ \\
\hline
\end{tabular}

Note: $* * * \mathrm{p}<0.01, * * \mathrm{p}<0.05, * \mathrm{p}<0.1$. All variables are defined in Table 1. 
Table 3. Correlation matrix

\begin{tabular}{|c|c|c|c|c|c|c|c|c|c|c|}
\hline Variables & 1 & 2 & 3 & 4 & 5 & 6 & 7 & 8 & 9 & 10 \\
\hline 1 COVIDSTAKACT & 1 & & & & & & & & & \\
\hline $2 S O C I A L$ & $0.16 * * *$ & 1 & & & & & & & & \\
\hline 3 SIZE & $0.21 * * *$ & $0.31 * * *$ & 1 & & & & & & & \\
\hline $4 R O E$ & 0 & 0.06 & -0.03 & 1 & & & & & & \\
\hline $5 L E V$ & -0.02 & 0.05 & $0.29 * * *$ & $0.39 * * *$ & 1 & & & & & \\
\hline 6 BTM & -0.03 & 0.03 & $0.19 * * *$ & $-0.11 *$ & 0.02 & 1 & & & & \\
\hline 7 ANAFOL & $0.28 * * *$ & $0.21 * * *$ & $0.47 * * *$ & 0.06 & -0.01 & -0.04 & 1 & & & \\
\hline 8 EARNREL & 0.09 & $0.19 * * *$ & $0.27 * * *$ & 0.01 & 0.08 & 0.08 & $0.26 * * *$ & 1 & & \\
\hline 9 CSRCOM & 0.07 & $0.37 * * *$ & $0.19 * * *$ & 0.01 & 0.06 & 0.07 & 0.07 & $0.26 * * *$ & 1 & \\
\hline 10 INDDIE & 0.08 & 0.03 & $0.18 * * *$ & 0.05 & 0.01 & -0.05 & $0.14 * *$ & 0.02 & -0.04 & 1 \\
\hline
\end{tabular}

Note: $* * * \mathrm{p}<0.01, * * \mathrm{p}<0.05, * \mathrm{p}<0.1$. All variables are defined in Table 1 . 
Table 4. Regression Analyses: The association between firms' social performance and their Twitter activity about stakeholder-oriented actions for the COVID-19 pandemic

\begin{tabular}{|c|c|c|c|}
\hline \multirow[b]{2}{*}{ Variables } & \multicolumn{3}{|c|}{ Dependent Variable: COVIDSTAKACT } \\
\hline & H1 & $\begin{array}{c}\mathrm{H} 2 \\
\text { Low impacted firms }\end{array}$ & $\begin{array}{c}\mathrm{H} 2 \\
\text { High impacted firms }\end{array}$ \\
\hline \multirow[t]{2}{*}{ SOCIAL } & $0.007 *$ & $0.031 * * *$ & 0.003 \\
\hline & $(0.004)$ & $(0.007)$ & $(0.005)$ \\
\hline \multirow[t]{2}{*}{ SIZE } & $0.296 * * *$ & 0.063 & $0.364 * * *$ \\
\hline & $(0.062)$ & $(0.124)$ & $(0.074)$ \\
\hline \multirow[t]{2}{*}{ ROE } & 0.030 & -0.221 & $0.576^{*}$ \\
\hline & $(0.037)$ & $(0.158)$ & $(0.310)$ \\
\hline \multirow[t]{2}{*}{ LEV } & $-0.013 * *$ & 0.024 & $-0.020 * * *$ \\
\hline & $(0.006)$ & $(0.028)$ & $(0.007)$ \\
\hline \multirow[t]{2}{*}{ BTM } & -0.015 & 0.422 & 0.005 \\
\hline & $(0.025)$ & $(0.266)$ & $(0.031)$ \\
\hline \multirow[t]{2}{*}{ ANAFOL } & $0.039 * * *$ & $0.044 * *$ & $0.029 *$ \\
\hline & $(0.012)$ & $(0.018)$ & $(0.015)$ \\
\hline \multirow[t]{2}{*}{ EARNREL } & -0.013 & -0.034 & -0.090 \\
\hline & $(0.152)$ & $(0.236)$ & $(0.193)$ \\
\hline \multirow[t]{2}{*}{ CSRCOM } & 0.240 & -0.164 & 0.268 \\
\hline & $(0.181)$ & $(0.260)$ & $(0.234)$ \\
\hline \multirow[t]{2}{*}{ INDDIR } & $0.006^{*}$ & 0.004 & 0.006 \\
\hline & $(0.003)$ & $(0.006)$ & $(0.004)$ \\
\hline \multirow[t]{2}{*}{ Constant } & $-7.158 * * *$ & $-4.237 *$ & $-8.261 * * *$ \\
\hline & (1.353) & $(2.462)$ & $(1.631)$ \\
\hline Observations & 483 & 126 & 357 \\
\hline Sample Firms & Pooled & Low Impact & High Impact \\
\hline Industry Group FE & YES & YES & YES \\
\hline Country FE & YES & YES & YES \\
\hline Pseudo R-squared & 0.09 & 0.18 & 0.09 \\
\hline
\end{tabular}

Note: Table 4 presents the results by regressing the number of tweets mentioning a firm's engagement in stakeholderoriented actions for the COVID-19 pandemic on firm social performance. Column 1 presents the results using a pooled sample and includes industry group and country fixed effect. Columns 2 and 3 separate the sample into low and high impact industries and examine the effect of firm social performance and low COVID-19 impact on firm engagement in COVID19 related actions. Robust standard errors in parentheses. $* * * \mathrm{p}<0.01, * * \mathrm{p}<0.05,{ }^{*} \mathrm{p}<0.1$. All variables are defined in Table 1. 
Table 5. Robustness check 1 - The effect of interaction between firms' social performance and participation in low impact industry on their Twitter activity about stakeholder-oriented actions for the COVID-19 pandemic

\begin{tabular}{|c|c|}
\hline \multirow{2}{*}{ Variables } & \multirow{2}{*}{$\begin{array}{c}\text { Dependent Variables: COVIDSTAKACT } \\
\mathbf{H 2}\end{array}$} \\
\hline & \\
\hline \multirow[t]{2}{*}{ SOCIAL } & $0.009 * *$ \\
\hline & $(0.005)$ \\
\hline \multirow[t]{2}{*}{ LOWIMPACT } & -0.751 \\
\hline & $(0.503)$ \\
\hline \multirow{2}{*}{ SOCIAL×LOWIMPACT } & $0.013 * *$ \\
\hline & $(0.006)$ \\
\hline \multirow[t]{2}{*}{ SIZE } & $0.191 * * *$ \\
\hline & $(0.045)$ \\
\hline \multirow[t]{2}{*}{ ROE } & $0.091^{*}$ \\
\hline & $(0.050)$ \\
\hline \multirow[t]{2}{*}{ LEV } & $-0.024 * * *$ \\
\hline & $(0.008)$ \\
\hline \multirow[t]{2}{*}{ BTM } & $-0.044 *$ \\
\hline & $(0.024)$ \\
\hline \multirow{2}{*}{ ANAFOL } & $0.026 * *$ \\
\hline & $(0.012)$ \\
\hline \multirow[t]{2}{*}{ EARNREL } & 0.117 \\
\hline & $(0.158)$ \\
\hline \multirow[t]{2}{*}{ CSRCOM } & 0.226 \\
\hline & $(0.181)$ \\
\hline \multirow[t]{2}{*}{ INDDIR } & 0.005 \\
\hline & $(0.004)$ \\
\hline \multirow[t]{2}{*}{ Constant } & $-5.218 * * *$ \\
\hline & $(0.961)$ \\
\hline Observations & 483 \\
\hline Sample Firms & Pooled \\
\hline Country Fixed Effect & YES \\
\hline Pseudo R-squared & 0.06 \\
\hline
\end{tabular}


Table 6. Robustness check 2 - The association between firms' overall CSR performance and their Twitter activity about stakeholder-oriented actions for the COVID-19

pandemic

\begin{tabular}{|c|c|c|c|}
\hline \multirow[b]{2}{*}{ Variables } & \multicolumn{3}{|c|}{ Dependent Variable: COVIDSTAKACT } \\
\hline & H1 & $\begin{array}{c}\mathrm{H} 2 \\
\text { Low impacted firms }\end{array}$ & $\begin{array}{c}\mathrm{H} 2 \\
\text { High impacted firms }\end{array}$ \\
\hline CSR & $\begin{array}{l}0.010 * * \\
(0.005)\end{array}$ & $\begin{array}{c}0.040 * * * \\
(0.008)\end{array}$ & $\begin{array}{c}0.004 \\
(0.006)\end{array}$ \\
\hline SIZE & $\begin{array}{c}0.284 * * * \\
(0.063)\end{array}$ & $\begin{array}{c}0.022 \\
(0.113)\end{array}$ & $\begin{array}{c}0.359^{* * *} \\
(0.076)\end{array}$ \\
\hline ROE & $\begin{array}{l}0.023 \\
(0.038)\end{array}$ & $\begin{array}{l}-0.307^{*} \\
(0.157)\end{array}$ & $\begin{array}{l}0.562 * \\
(0.311)\end{array}$ \\
\hline LEV & $\begin{array}{c}-0.013 * * \\
(0.006)\end{array}$ & $\begin{array}{c}0.037 \\
(0.027)\end{array}$ & $\begin{array}{c}-0.020 * * * \\
(0.007)\end{array}$ \\
\hline BTM & $\begin{array}{l}-0.018 \\
(0.025)\end{array}$ & $\begin{array}{c}0.328 \\
(0.264)\end{array}$ & $\begin{array}{c}0.004 \\
(0.031)\end{array}$ \\
\hline ANAFOL & $\begin{array}{c}0.039 * * * \\
(0.012)\end{array}$ & $\begin{array}{l}0.034 * * \\
(0.017)\end{array}$ & $\begin{array}{l}0.029 * * \\
(0.015)\end{array}$ \\
\hline EARNREL & $\begin{array}{l}-0.032 \\
(0.153)\end{array}$ & $\begin{array}{l}-0.172 \\
(0.229)\end{array}$ & $\begin{array}{l}-0.096 \\
(0.193)\end{array}$ \\
\hline CSRCOM & $\begin{array}{c}0.226 \\
(0.183)\end{array}$ & $\begin{array}{l}-0.287 \\
(0.245)\end{array}$ & $\begin{array}{c}0.265 \\
(0.229)\end{array}$ \\
\hline INDDIR & $\begin{array}{c}0.005 \\
(0.003)\end{array}$ & $\begin{array}{c}0.001 \\
(0.005)\end{array}$ & $\begin{array}{c}0.005 \\
(0.004)\end{array}$ \\
\hline Constant & $\begin{array}{c}-6.956 * * * \\
(1.364)\end{array}$ & $\begin{array}{l}-3.497 \\
(2.240)\end{array}$ & $\begin{array}{c}-8.193 * * * \\
(1.651)\end{array}$ \\
\hline Observations & 483 & 126 & 357 \\
\hline Sample Firms & Pooled & Low Impact & High Impact \\
\hline Industry Group FE & YES & YES & YES \\
\hline Country FE & YES & YES & YES \\
\hline Pseudo R-squared & 0.09 & 0.19 & 0.09 \\
\hline
\end{tabular}

Note: Table 6 presents the results by regressing the number of tweets mentioning a firm's engagement in stakeholderoriented actions for the COVID-19 pandemic on firm overall CSR performance. Column 1 presents the results using a pooled sample and includes industry group and country fixed effect. Columns 2 and 3 separate the sample into low and high impact industries and examine the effect of firm overall CSR performance and low COVID-19 impact on firm engagement in COVID-19 related actions. Robust standard errors in parentheses. $* * * \mathrm{p}<0.01, * * \mathrm{p}<0.05, * \mathrm{p}<0.1$. All variables are defined in Table 1 . 
Table 7. Robustness check 3 - The association between firms' social performance and their Twitter activity about all actions for the COVID-19 pandemic

\begin{tabular}{|c|c|c|c|}
\hline \multirow[b]{2}{*}{ Variables } & \multicolumn{3}{|c|}{ Dependent Variables: COVIDACT } \\
\hline & H1 & $\begin{array}{c}\mathrm{H} 2 \\
\text { Low impacted firms }\end{array}$ & $\begin{array}{c}\mathrm{H} 2 \\
\text { High impacted firms }\end{array}$ \\
\hline \multirow[t]{2}{*}{ SOCIAL } & $0.007^{*}$ & $0.030 * * *$ & 0.003 \\
\hline & $(0.004)$ & $(0.007)$ & $(0.005)$ \\
\hline \multirow[t]{2}{*}{ SIZE } & $0.275 * * *$ & 0.059 & $0.326^{* * *}$ \\
\hline & $(0.059)$ & $(0.122)$ & $(0.070)$ \\
\hline \multirow[t]{2}{*}{ ROE } & 0.010 & -0.225 & 0.477 \\
\hline & $(0.032)$ & $(0.153)$ & $(0.305)$ \\
\hline \multirow[t]{2}{*}{ LEV } & $-0.010 * *$ & 0.024 & $-0.014 * * *$ \\
\hline & $(0.005)$ & $(0.027)$ & $(0.005)$ \\
\hline \multirow[t]{2}{*}{ BTM } & -0.024 & $0.490 *$ & -0.002 \\
\hline & $(0.024)$ & $(0.261)$ & $(0.029)$ \\
\hline \multirow[t]{2}{*}{ ANAFOL } & $0.033 * * *$ & $0.036 * *$ & $0.024 *$ \\
\hline & $(0.012)$ & $(0.018)$ & $(0.014)$ \\
\hline \multirow[t]{2}{*}{ EARNREL } & 0.104 & 0.106 & 0.026 \\
\hline & $(0.143)$ & $(0.231)$ & $(0.182)$ \\
\hline \multirow[t]{2}{*}{ CSRCOM } & 0.181 & -0.184 & 0.265 \\
\hline & $(0.173)$ & $(0.234)$ & $(0.227)$ \\
\hline \multirow[t]{2}{*}{ INDDIR } & 0.004 & 0.003 & 0.003 \\
\hline & $(0.003)$ & $(0.006)$ & $(0.003)$ \\
\hline \multirow[t]{2}{*}{ Constant } & $-6.405 * * *$ & -3.856 & $-7.168 * * *$ \\
\hline & $(1.282)$ & $(2.423)$ & $(1.525)$ \\
\hline Observations & 483 & 126 & 357 \\
\hline Sample Firms & Pooled & Low Impact & High Impact \\
\hline Industry Group FE & YES & YES & YES \\
\hline Country FE & YES & YES & YES \\
\hline Pseudo R-squared & 0.08 & 0.15 & 0.08 \\
\hline \multicolumn{4}{|c|}{$\begin{array}{l}\text { Note: Table } 7 \text { presents the results by regressing the number of tweets mentioning a firm's general response to the COVID } \\
19 \text { pandemic on firm's social performance. Column } 1 \text { presents the results using a pooled sample and includes industry } \\
\text { group and country fixed effect. Columns } 2 \text { and } 3 \text { separate the sample into low and high impact industries and examine the } \\
\text { effect of firm social performance and low COVID-19 impact on firm engagement in COVID-19 related actions. Robus } \\
\text { standard errors in parentheses. } * * * p<0.01, * * p<0.05, * p<0.1 \text {. All variables are defined in Table } 1 \text {. }\end{array}$} \\
\hline
\end{tabular}


Table 8. Robustness check 4 - Estimation of OLS linear model

\begin{tabular}{|c|c|c|c|}
\hline \multirow[b]{2}{*}{ Variables } & \multicolumn{3}{|c|}{ Dependent Variables: LNSTAKACT } \\
\hline & H1 & $\begin{array}{c}\mathrm{H} 2 \\
\text { Low impacted firms }\end{array}$ & $\begin{array}{c}\mathrm{H} 2 \\
\text { High impacted firms }\end{array}$ \\
\hline SOCIAL & $\begin{array}{c}0.005 * * \\
(0.003)\end{array}$ & $\begin{array}{c}0.020 * * * \\
(0.006)\end{array}$ & $\begin{array}{c}0.003 \\
(0.003)\end{array}$ \\
\hline SIZE & $\begin{array}{c}0.202 * * * \\
(0.042)\end{array}$ & $\begin{array}{c}0.020 \\
(0.111)\end{array}$ & $\begin{array}{c}0.240 * * * \\
(0.050)\end{array}$ \\
\hline ROE & $\begin{array}{c}0.006 \\
(0.017)\end{array}$ & $\begin{array}{l}-0.242 \\
(0.153)\end{array}$ & $\begin{array}{l}0.314 * \\
(0.189)\end{array}$ \\
\hline LEV & $\begin{array}{c}-0.007 * * * \\
(0.001)\end{array}$ & $\begin{array}{c}0.031 \\
(0.026)\end{array}$ & $\begin{array}{c}-0.008 * * * \\
(0.002)\end{array}$ \\
\hline BTM & $\begin{array}{l}-0.003 \\
(0.015)\end{array}$ & $\begin{array}{c}0.183 \\
(0.296)\end{array}$ & $\begin{array}{c}0.007 \\
(0.018)\end{array}$ \\
\hline ANAFOL & $\begin{array}{c}0.016 \\
(0.010)\end{array}$ & $\begin{array}{l}0.032 * \\
(0.018)\end{array}$ & $\begin{array}{c}0.014 \\
(0.011)\end{array}$ \\
\hline EARNREL & $\begin{array}{l}-0.001 \\
(0.108)\end{array}$ & $\begin{array}{l}-0.055 \\
(0.232)\end{array}$ & $\begin{array}{l}-0.013 \\
(0.130)\end{array}$ \\
\hline CSRCOM & $\begin{array}{c}0.099 \\
(0.116)\end{array}$ & $\begin{array}{l}-0.117 \\
(0.223)\end{array}$ & $\begin{array}{c}0.118 \\
(0.143)\end{array}$ \\
\hline INDDIR & $\begin{array}{c}0.003 \\
(0.002)\end{array}$ & $\begin{array}{c}0.001 \\
(0.005)\end{array}$ & $\begin{array}{c}0.003 \\
(0.002)\end{array}$ \\
\hline Constant & $\begin{array}{c}-4.095 * * * \\
(0.913)\end{array}$ & $\begin{array}{l}-1.648 \\
(2.152)\end{array}$ & $\begin{array}{c}-4.770 * * * \\
(1.090)\end{array}$ \\
\hline Observations & 483 & 126 & 357 \\
\hline Sample Firms & 0.338 & 0.527 & 0.329 \\
\hline Industry Group FE & Pooled & Low Impact & High Impact \\
\hline Country FE & YES & YES & YES \\
\hline Pseudo R-squared & YES & YES & YES \\
\hline
\end{tabular}

Note: Table 8 presents the results by regressing the natural log of the number of tweets mentioning a firm's engagement in stakeholder-oriented actions for the COVID-19 pandemic on firm social performance using OLS model. A value of one is added to the number before taking natural logarithm. Column 1 presents the results using a pooled sample and includes industry group and country fixed effect. Columns 2 and 3 separate the sample into low and high impact industries and examine the effect of firm social performance and low COVID-19 impact on firm engagement in COVID-19 related actions. Robust standard errors in parentheses. ${ }^{* *} \mathrm{p}<0.01, * * \mathrm{p}<0.05, * \mathrm{p}<0.1$. All variables are defined in Table 1. 
Table 9. Robustness check 5: The association between firms' social performance and their Twitter activity about stakeholder-oriented actions for the COVID-19 pandemic in Countries with High Death Rate

\begin{tabular}{|c|c|c|c|}
\hline \multirow[b]{2}{*}{ Variables } & \multicolumn{3}{|c|}{ Dependent Variable: COVIDSTAKACT } \\
\hline & H1 & $\begin{array}{c}\mathrm{H} 2 \\
\text { Low impacted firms }\end{array}$ & $\begin{array}{c}\mathrm{H} 2 \\
\text { High impacted firms }\end{array}$ \\
\hline SOCIAL & $\begin{array}{l}0.009 * \\
(0.006)\end{array}$ & $\begin{array}{c}0.015 * * \\
(0.007)\end{array}$ & $\begin{array}{c}0.009 \\
(0.008)\end{array}$ \\
\hline SIZE & $\begin{array}{c}0.416 * * * \\
(0.073)\end{array}$ & $\begin{array}{c}0.445 * * * \\
(0.143)\end{array}$ & $\begin{array}{c}0.473 * * * \\
(0.091)\end{array}$ \\
\hline ROE & $\begin{array}{c}0.046 \\
(0.037)\end{array}$ & $\begin{array}{c}-0.397 * * * \\
(0.119)\end{array}$ & $\begin{array}{c}0.681 * * \\
(0.346)\end{array}$ \\
\hline LEV & $\begin{array}{c}-0.015 * * * \\
(0.005)\end{array}$ & $\begin{array}{c}0.061 * * * \\
(0.020)\end{array}$ & $\begin{array}{c}-0.021 * * * \\
(0.007)\end{array}$ \\
\hline BTM & $\begin{array}{c}-0.144 * \\
(0.076)\end{array}$ & $\begin{array}{c}-0.298 \\
(0.268)\end{array}$ & $\begin{array}{l}-0.070 \\
(0.089)\end{array}$ \\
\hline ANAFOL & $\begin{array}{c}0.033^{* *} \\
(0.015)\end{array}$ & $\begin{array}{c}0.014 \\
(0.026)\end{array}$ & $\begin{array}{c}0.018 \\
(0.021)\end{array}$ \\
\hline EARNREL & $\begin{array}{l}-0.255 \\
(0.217)\end{array}$ & $\begin{array}{l}-0.438 * \\
(0.234)\end{array}$ & $\begin{array}{l}-0.442 \\
(0.309)\end{array}$ \\
\hline CSRCOM & $\begin{array}{c}0.151 \\
(0.240)\end{array}$ & $\begin{array}{l}-0.161 \\
(0.312)\end{array}$ & $\begin{array}{c}0.170 \\
(0.346)\end{array}$ \\
\hline INDDIR & $\begin{array}{l}-0.004 \\
(0.005)\end{array}$ & $\begin{array}{c}0.001 \\
(0.006)\end{array}$ & $\begin{array}{l}-0.010 \\
(0.008)\end{array}$ \\
\hline Constant & $\begin{array}{c}-9.441 * * * \\
(1.552)\end{array}$ & $\begin{array}{c}-9.941 * * * \\
(2.914)\end{array}$ & $\begin{array}{c}-10.138 * * * \\
(1.855)\end{array}$ \\
\hline Observations & 277 & 85 & 192 \\
\hline Sample Firms & Pooled & Low Impact & High Impact \\
\hline Industry Group FE & YES & YES & YES \\
\hline Pseudo R-squared & 0.09 & 0.14 & 0.09 \\
\hline $\begin{array}{l}\text { Note: Table } 9 \text { present } \\
\text { oriented actions for the } \\
\text { include Belgium, Spai } \\
\text { sample and includes in } \\
\text { and examine the effec } \\
\text { actions. Robust standa }\end{array}$ & $\begin{array}{l}\text { egressing } \\
\text { emic on fi } \\
\text { therlands, } \\
\text { d effect. } \\
\text { erformance } \\
\text { theses. } * *\end{array}$ & $\begin{array}{l}\text { tweets mentioning a fir } \\
\text { rmance in countries with } \\
\text { ad and USA. Column } 1 \mathrm{p} \\
3 \text { separate the sample int } \\
\text { ID-19 impact on firm e } \\
0.05, * \text { p }<0.1 \text {. All varial }\end{array}$ & $\begin{array}{l}\text { ngagement in stakeholder- } \\
\text { death rate. These countries } \\
\text { s the results using a pooled } \\
\text { and high impact industries } \\
\text { ment in COVID-19 related } \\
\text { e defined in Table } 1 \text {. }\end{array}$ \\
\hline
\end{tabular}

